\title{
Measuring Level of Job Satisfaction-A Study of Employees at Al-Islam Trading Company for Auto Spare Parts
}

\author{
Dr. Amir Abou Elnaga \\ Vice Dean of College of Business Administration \\ Assistant Professor, Dar Al Uloom University \\ Riyadh, Kingdom of Saudi Arabia \\ E-mail: amirzaki78@hotmail.com
}

Received: Dec. 5, 2012 Accepted: January 7, 2012 Published: January 8, 2013

doi:10.5296/jmr.v5i1.2805 URL: http://dx.doi.org/10.5296/jmr.v5i1.2805

\begin{abstract}
Job satisfaction represents one of the most complex areas facing today's managers when it comes to managing their employees. Many studies have demonstrated an unusually large impact on the job satisfaction on the motivation of workers,

The objective of this research was to investigate certain factors and its impact on job satisfaction of employees at El- Isalam Trading Company. Specifically, this study addresses three points motivation, internal work environment and reducing the working days to be 5 instead of 6 days a week by increasing working hour to be 8 hour instead of 6 hour per day.

Based on the conceptual framework of the study, Likert-type questionnaire (Minnesota Satisfaction questionnaire with some adjustments by the researcher) was filled by (58) employees, which participated in this research by completing the questionnaire. With the assistance of statistical analyses, it was found that the employees in El Isalam Trading company have a high degree of job satisfaction influenced by their motivation, satisfaction of work environment and that they prefer to reduce the working week days to be 5 days and there is no significant relation between job satisfaction and gender, level of education \& social status. employees in El Isalam Trading Company.
\end{abstract}

Keywords: Job satisfaction, Motivation, Work environment, Al-Islam trading company for import and export auto spare parts 


\section{Introduction}

Al-Islam Trading Co. was established in 1975 by Mohamed Zaki Shama as an entrepreneurial venture. The company is working in the field of importing of Auto spare parts. Main imports are form Italy, Turkey and South Korea. The number of employee is 58 employees. The main branch is in El Ibrahimeya Alexandria, while the outlet is located in Lauran. The competing companies in Alexandria are around 30 companies.

This research is conducted to provide specific factors relating to job satisfaction, which would benefit the employers of El Islam Trading Company.

We all talk about job satisfaction, what it means to us, to society and to the organization. But how many of us really know what job satisfaction is? The sad truth is not many of us know what Job satisfaction is all about. Researchers and psychologists have spent years in trying to find out what job satisfaction is, what affects it and what not.

Job satisfaction means different things to different people; this is because job satisfaction has a lot of do with motivation. People are motivated by different things to do different things. While this is true, do not confuse and mistake job satisfaction as being the same as motivation.

A simple definition of Job satisfaction " Job satisfaction is more an attitudle, an internal state. It could, for example, be associated with a personal feeling of achievement, either quantitative or qualitative." There are different aspects to job satisfaction, some will agree whole-heartedly to this and some will disagree. So what are the different dimensions or aspects of job satisfaction?

Individual elements - this means personality, education, intellect, age and marital status. These individual elements play an important role in job satisfaction.

Social elements - social elements are all things in the social environment of the work place, such as working relationship with colleagues, interaction and informal association with colleagues.

Cultural elements - these are a person’s beliefs, attitude, values, religious elements.

Organizational elements - these are elements directly related to the organization like the size of the organization, structure of the organization, employee-employer relationships, management abilities, leaderships, delegation and all such things are factors affecting job satisfaction.

Environmental elements - these are elements of influences on the environment around working, like economic, social, technical and even governmental or political influences.

All these factors, elements or dimensions are very different for each individual and his or her perspective of job satisfaction. One of the best ways people have realized to get a grip on job satisfaction is to establish the right kind of culture in their organizations, this is often called corporate culture. 


\section{Macrothink}

\section{Literature Review}

Job satisfaction definitions: - Job satisfaction has been defined as:

A pleasurable emotional state resulting from the appraisal of one’s job (1)

An affective reaction to one's job

An attitude towards one’s job (3)

Weiss (2002) has argued that job satisfaction is an attitude but points out that researchers should clearly distinguish the objects of cognitive evaluation which are affect (emotion), beliefs and behaviours. .(4) This definition suggests that we form attitudes towards our jobs by taking into account our feelings, our beliefs, and our behaviors.

The satisfaction or utility that a worker receives from employment. Job satisfaction might result from the working environment (friendly co-workers, supportive boss) or from the type of work performed (playing sports, creating artwork, accomplishing goals). Satisfaction generated by a job is part of the "total compensation" an employee receives, meaning workers with more job satisfaction are often willing to accept a lower monetary wage payment.

Job satisfaction describes how content an individual is with his or her job. A person's general attitude towards their job. the feelings or 'affective response' someone experiences in a job role.

Across a variety of studies, research shows that job satisfaction is an important predictor of job performance. A happy worker is a productive worker. The job satisfaction-job performance relationship .(5)

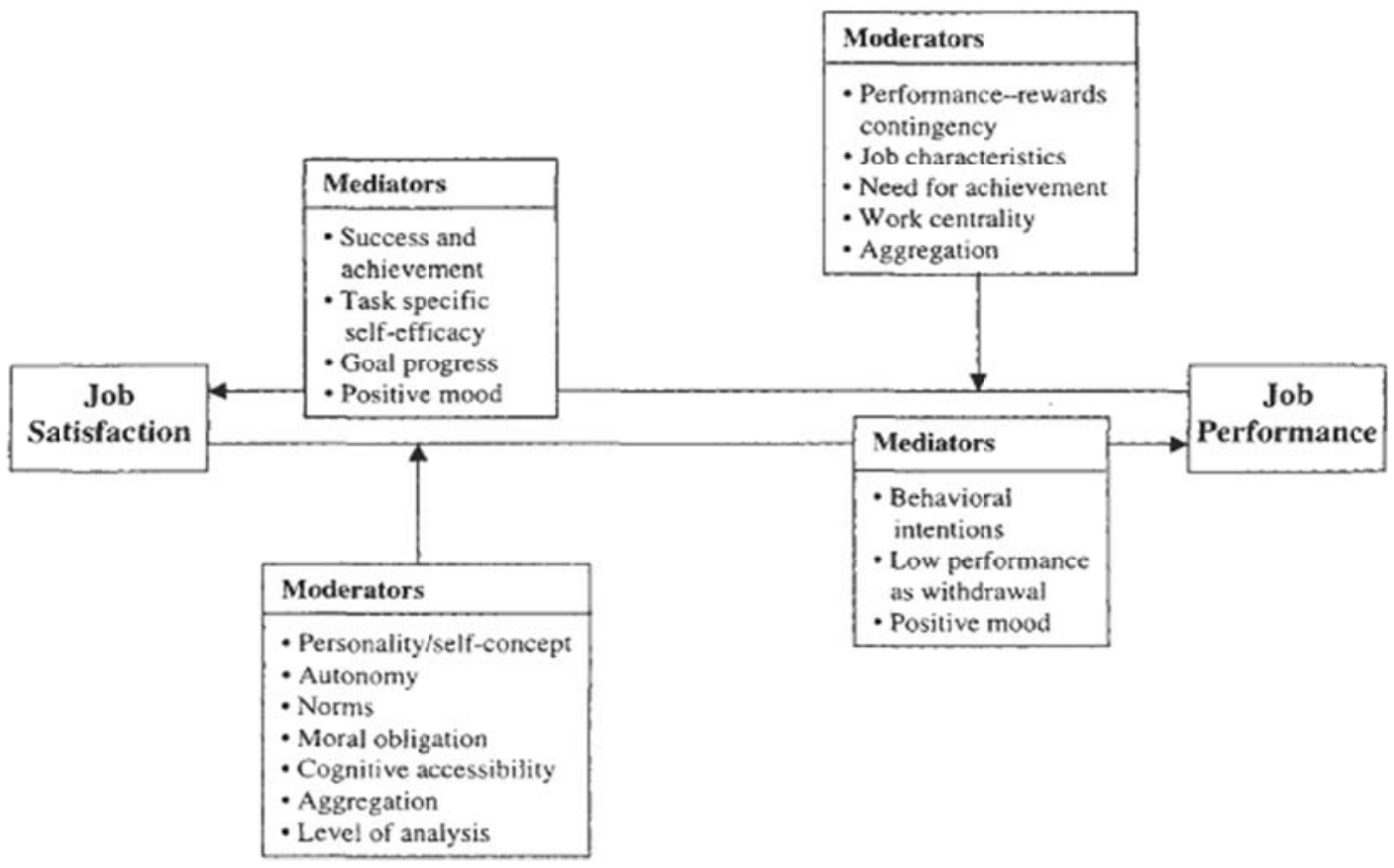

Figure 2. Integrative model of the relationship between job satisfaction and job performance. 
As the above diagram shows, the relationship between job satisfaction and job performance is complex, and likely cyclical. Studies have shown that increased job satisfaction leads to increased motivation (behavioral intentions), less apathy (low performance as withdrawal), and better worker mood, all of which increase efficiency and overall quality of job performance.

\section{Motivation and job satisfaction}

In order to understand job satisfaction, it is important to understand what motivates people at work. Motivation can be defined in many different ways, one definition explains that motivation can be defined as a stimulus, a drive or incentive in this case, that drives individuals to accomplish personal and organizational goals. Psychologists have long studied the aspects that lead to job satisfaction for employees and attempt to expllain what motivates people to achieve success not only for themselves, but for their company as well.

Many researchers agree that understanding the factors that lead to job satisfaction is a difficult problem that is often on the minds of management in most companies. If certain factors are known to motivate most people most of the time, then these factors could be used to create more employees who are satisfied with their work and in turn would lead to a more productive company overall. (6).

One of the most popular motivation theories, frequently referred to as the hierarchy of needs theory, was proposed in the 1940's by Abraham Maslow. According to Maslow, people are motivated by their desire to satisfy specific needs. Maslow arranged these needs in hierarchical order, with physiological needs at the bottom, followed by safety needs, social and belongingness needs, esteem needs, and, at the top, self-actualization needs. In general, lower-level needs must be substantially met before higher-level needs become important (7).

Regarded the first two need levels (physiological and safety) as lower-order needs. These needs are also called deficiency needs because if these needs are not met, people may not have the opportunity to develop themselves both physically and physiologically. In order to survive people need air, water, food and protection from physical danger. Many people work in order to survive, to provide themselves with the means to guarantee themselves and their families sufficient nourishment and protection from harm. These survival needs are very powerful motivators for people to go to work; people whose survival is threatened will work in almost any kind of job so they can earn enough money to meet their lower-order needs.

Psychologist Frederick Herzberg is one of the best-known theorists regarding workplace motivation. Herzberg's two-factor theory of job satisfaction.

The key to understanding Herzberg's Motivation-Hygiene Theory is that the factors that involve job content (motivation factors) tend to lead to job satisfaction. When these factors are not present on the job, workers do not tend to be dissatisfied - they are simply are "not satisfied.” Workers who are "not satisfied" do not tend to restrict productivity, they just don't get involved in their job or put forth the extra effort to do a good job. Workers who are "satisfied" put forth that extra effort and productivity increases. 
Factors that involve job context (hygiene factors) tend to lead to job dissatisfaction. When these factors are considered good, or acceptable, workers do not tend to become "satisfied“, they simply become "not dissatisfied." Productivity is not restricted - it is just held at an acceptable level. When

workers become dissatisfied with any of these factors they tend to restrict output. (8).

I can summarize in the following table for these factor

\begin{tabular}{|l|l|}
\hline Motivation Factors & Hygiene Factors \\
\hline Achievement & Working Conditions \\
\hline Work Itself & Supervision \\
\hline Responsibility & Interpersonal Relations \\
\hline Growth & Status \\
\hline Advancement & Company Policies \& Administration \\
\hline Recognition & Security \\
\hline
\end{tabular}

The nature of the work performed by employees has a significant impact on their level of job satisfaction.Internal work environment is made up of a range of factors, including company culture, management styles, hierarchies and human resources policies. Employee satisfaction is the degree to which employees feel personally fulfilled and content in their job roles. Employee turnover is the rate at which employees leave their employers, whether voluntarily or involuntarily. These three distinct concepts are inseparably linked; workplace environments greatly influence employee satisfaction, which in turn directly affects employee turnover rates. Knowing how to use a positive work environment to increase employee satisfaction and reduce turnover is a key to developing a high-performance workforce. ${ }^{(9)}$.

\section{Researcher view}

I suggest that Maslow's and Herzburg's theories of motivation are more useful for motivation at this time. Maslow's theory indicates that the key to motivating people isi understanding that they are motivated by needs, which are arranged in a hierarchy of importance. This hierarchy is known as Maslow's need hierarchy. Maslow explains that people seek to satisfy needs at the lowest level of the hierarchy before trying to satisfy needs on the next higher level. Maslow believed that motivation could be examined in terms of five sets of needs: physiological, safety, social, esteem and self-actualization. Maslow argued that as we satisfy any of these five sets of needs, that set becomes less important to us and motivates us less. Maslow's need hierarchy provides useful perspectives for understanding motivation. This theory of motivation inspired other research work on motivation. Herzberg introduced two-factor model. The factors associated with positive feelings about the job are called motivator factors. Motivator factors are job characteristics such as challenge of the work itself, responsibility, recognition, achievement, and advancement and growth. These factors determine whether a job is exciting and rewarding, and they create high levels of motivation unless other dissatisfying factors are present. Those associated with feelings of dissatisfaction are called dissatisfying factors. These are characteristics of the work environment outside the 
job but inside the company, for example: working conditions, company policies, supervision style, colleagues in work, salary, formal status.

If we see these two theories, we can say that Herzberg's dissatisfactions factors seem to fit with Maslow's lower level needs, while his motivating factors fit closely with Maslow's esteem and self-actualization needs. Both the theories concentrate more on employee not on organization. Maslow's concentration is all categories of employees while Herzberg on higher and qualified employees. Both theories take human factor and behavioral factor as key to stress on.

Motivation is very important factor in the success of any company. Motivation is to give people what they really want most from work. The more the companies are able to provide what they want, the more they should expect what the companies really want. Motivation is more than simply working hard or completing tasks. Employees can find motivation from a variety of sources. Motivation will come from the enjoyment of the work itself or from the desire to achieve more money or being promoted. It also comes from the sense of satisfaction gained from completing something, or achieving a successful outcome. There are many more benefits to an organization of having a motivated employees. I will write some benefits which are more important and clear for knowing. They are following:

(1) Motivated employees are more loyal to organization. Loyalty give many benefits to the organization.

(2) The productivity will also increase. Higher productivity per employee will lead to lower unit costs of production and so enable a firm to sell its product at a lower price. The organization will be in better position to compete with other similar organizations. Also it will maximize profit.

(3) Employees will work as tools of live advertisement. They will propagate their organizations while they mix up with their fellow outside the organization. The organization will have good prevailing reputation. Employees will not be absent from their works as employees are content with their working with organization.

(4) Any organization having motivated employees will not lose the quality of products. As employees are motivated, they will take care of quality from their hurts. They will never compromise on quality of product.

(5)Staff turnover (the number of employees leaving the business) will be at the least. This will lower the cost of HRM.

\section{Summary of literature review}

By understanding the effects of different motivation techniques, companies are able to make work a more exciting and interesting experience for employees making them more motivated and productive. Here is a brief discussion on how different motivation theories are being used according to the situation to get the employees motivated. Taylor's theory of motivation believed that monetary reward is an important motivating factor. Companies apply Taylor's 
view of motivation to people who work within narrow job confines such as on a production line. These people are paid by companies according to the amount of work.

Hierarchal Needs theory of Maslow relates motivation to a hierarchy of needs. Maslow suggests that it is necessary to know where within the hierarchy each employee is placed so that these factors can be taken into account. Modern organizations follow the ladder of motivation given by Maslow. At the first stage physiological needs, companies give people the means to acquire the basic needs for living. The organizations are committed to providing a safe and healthy work environment. Thirdly, companies develop feeling of belonging to the company through different measure to fulfill the social needs of employees. Companies organize functions, get together events, games, etc. This helps strengthen teams and enhances workers' sense of belonging. Esteem needs are fulfilled by companies by trying that all employees should feel that they contribute to the achievements of the business. Companies appreciate their excellent employees through different means which fulfill sense of esteem in them. Lastly, self-actualization - Companies provide employees with the opportunity to take on challenging and stimulating responsibilities. All these motivate.

Elton Mayo focuses on building close relationship with the employees. Mayo showed that employees were best motivated if they worked in teams. They were also motivated if managers communicate and consult with them more and take a greater interest in their views. Organizations maintain a two-way dialogue with employees through their communication programmes. This helps to empower the workforce. Companies' award programmes provides special recognition for what employees do and rewards them for how they perform. The suggestion from the employees helps to generate ideas and improve productivity. Companies provide personal development planning for employees which includes provisions such as study leave as part of staff development. Consequently, they are more enthusiastic and ambitious to work.

Two-factor Theory of Herzberg's includes motivators and dissatisfiers. Both are aspects of any workplace that give individuals job satisfaction. He believed that businesses needed to minimize dissatisfiers to enable motivators to have their full effect. These are elements in the workplace that could make employees unhappy, such as excessive company bureaucracy or misbehavior of managers. Usually, companies design to ensure that it is perceived as a good place to work and a desirable employer of choice. Awareness of motivating factors helps companies to build a business that delivers consistently strong results. Other initiatives within the organization may include: home working, part-time working, career breaks etc. A new trend of working is flexible working hours between home and workplace. This is highly productive.

\section{Research problem}

There is no enough information about the level of job satisfaction For the employees working at Al-Islam trading company for auto spare parts

the following research problem was identified: 


\section{Macrothink}

"To what extent do factors such motivation, internal work environment and minimizing working days to 5 days affect on job satisfaction “

\section{Research purpose}

The purpose of the research was to investigate level of job satisfaction For the employees working at Al-Islam trading company for auto spare parts

\section{Research importance}

Job satisfaction is one of the most researched areas of organizational behavior and education. It is perceived as an attitudinal variable measuring the degree to which employees like their jobs and the various aspects of their jobs.This is an important area of research because job satisfaction is correlated to enhanced job performance, positive work values, high levels of employee motivation, and lower rates of absenteeism, turnover and burnout Also It is the first time to measure level of job satisfaction For the employees working at Al-Islam trading company for auto spare parts

There is no scientific research to measure and analyze this problems, In addition, how can owner of Al-Islam trading company affect in their work satisfaction

\section{Research objectives}

The primary objective of this study was to investigate the relationship between motivation and internal work environment and job satisfaction. The study also investigated the relationship between reducing the working days to be 5 days instead of 6 days a week by increasing working hour to be 8 per day hour instead of 6 hour

To achieve the primary objective, the following secondary objectives were investigated:

(i) A review study of motivation factors was conducted to establish whether

it impacts on job satisfaction.

(ii) A review study of internal work environment condition was conducted to establish whether it impacts on job satisfaction

(iii) A review study workload was conducted to establish whether it impacts on job satisfaction.

\section{Research Methodology}

This study is empirical in nature and it is conducted through questionnaires. The target population of 48 employees working at Al-Islam trading company for auto spare parts

The data collection tool is questionnaire. The Minnesota Satisfaction Questionnaire was used, while some amendments to the questions were done by the researcher to serve in obtaining the answers for the research's questions, and to validate the research's hypothesis.

\section{Research Questions}

1. Is there a relationship between employee motivation and job satisfaction? 
2. Is there a relationship between work environment and job satisfaction?

3. Is there a relationship between reducing the working days and job satisfaction?

\section{Research Hypothesis}

H1: There is a significant correlation between motivation and job satisfaction for the employees working at Al-Islam trading company for auto spare parts

$\mathrm{H} 2$ : There is a significant correlation between work environment and job satisfaction for the employees working at Al-Islam trading company for auto spare parts

H3: There is a significant correlation between reducing the weekly working days to 5 days and job satisfaction. For the employees working at Al-Islam trading company for auto spare parts

\section{Research Limitations:}

L1. Location of this research: - Al-Islam trading company for auto spare parts

L2.Period of this research: - one month

\section{Data Collection}

1. Primary Data was collected by the researchers. (questionnaire data)

2. Secondary Data was collected from the internet, El Islam Trading company records.

\section{Research variables:}

Independent Variables

\section{Dependant Variable}

Motivation

Work Environment

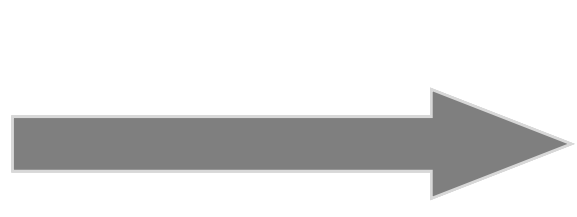

Weekly Working

days

$$
\uparrow
$$

\section{Intervening Variables}

(Demographics)

Gender

Years Of

Experience

Education

Social Status 
Each Variable is divided into tackled in the questionnaire sequence:

\section{A- Motivation}

Q1. Salary being appropriate to the job.

Q2. Incentives, benefits and bonuses being appropriate for the job.

Q3. Opportunity to get promoted and improve job position.

Q4. Job is appropriate with the years of experience.

Q5. Feeling secured with current and future job.

Q6. Being respected and appreciated for performing the job from everyone.

\section{B- Work environment}

Q7. Work group cooperation and good relations.

Q8. Type of supervision.

Q9. Degree of freedom and independence in performing my job

Q10. Coordination between the different job divisions.

Q11. Available capabilities that enable work development and improving performance.

Q12. Suitable working conditions are suitable / cleanliness, ventilation and equipment.

\section{C- Weekly working days}

Q13. The job/ work design enables two days off instead of one day only.

Q14. The capability to accomplish the week's work in 5 days instead of 6 .

Q15. Eight hour working per day is sufficient to perform your work efficiently

The Dependant variable:

\section{D- Job satisfaction}

Q18. feel happy performing my job

Q19. I trust I can achieve success and my ambition through my current job.

Q20. I feel belonging and loyalty towards my job and my company.

Note: Q16, Q17 and Q18 are verifying questions, to reassure the respondents credibility.

\section{The Intervening variables}

These are the demographics which play an important role in the employees perception of job satisfaction. In this research they are defined as gender, years of experience, education and 
social status. It is argued that these attribute affects the employees over all decisions. They are questioned in the first part of the questionnaire.

The Questionnaire included 20 closed ended questions, with five demographic questions, the name of the respondent was optional, while the respondent answered the questions related to gender, age, years of experience, education and social status.

The number of employees is 75 , while the correct questionnaires gathered were only 58 questionnaires.

The questionnaire was designed using Lickert scale.

\begin{tabular}{|l|l|}
\hline 1 & Very Dissatisfied \\
\hline 2 & Dissatisfied \\
\hline 3 & Neutral \\
\hline 4 & Satisfied \\
\hline 5 & Very Satisfied \\
\hline
\end{tabular}

Validity of the questionnaire: The use of Minnesota Satisfaction questionnaire, which is a very reputable questionnaire, while adjusting some questions to serve the purpose of the research.

Reliability of the questionnaire: 10 of the questionnaires were redistributed for a second time in a one week interval to the same employees and the answers were very much the same with minor non significant differences.

The research analysis were done using the Statistical Package For Social Science SPSS software to analyze the data gathered in the questionnaires.

Following table shows the entry of variables to the SPSS

\section{SPSS results}

The research analysis were done using the Statistical Package For Social Science SPSS software to analyze the data gathered in the questionnaires.

Following table shows the entry of variables to the SPSS

\begin{tabular}{|l|l|l|}
\hline Variable & Question number & Code \\
\hline Motivation & $1,2,3,4,5,6$ & Moti_01,02,03,04,05,06 \\
\hline Work environment & $7,8,9,10,11,12$ & Envi_01,02,03,04,05,06 \\
\hline Changing the weekly working days & $13,14,15$ & Ww._01,012,03 \\
\hline Job satisfaction & $16,17,18,19,20$ & Satis_01,02,03,04,05 \\
\hline
\end{tabular}

\section{Research Outcome}

The research indicates that job satisfaction has a direct impact on the following aspects: 
- The level of individual as well as organizational performance.

- Efficiency to achieve organizational goals.

- $\quad$ Recruiting and retaining high caliber Human resources.

- Economical costing and best utility of resources.

\section{SPSS results}

Independent Variables/ Dependant Variable:

\begin{tabular}{|l|l|l|l|}
\hline & $\begin{array}{l}\text { Work } \\
\text { environment }\end{array}$ & $\begin{array}{l}\text { Changing the weekly } \\
\text { working days }\end{array}$ & Job satisfaction \\
\hline Motivation & 0.869 & -2.77 & 0.938 \\
\hline Work environment & & -0.161 & 0.936 \\
\hline $\begin{array}{l}\text { Changing the weekly working } \\
\text { days }\end{array}$ & & & -0.98 \\
\hline
\end{tabular}

Intervening Variables / Dependant Variable

\begin{tabular}{|l|l|l|l|l|}
\hline & Education & Experience & Social status & Job Satisfaction \\
\hline Gender & -0.122 & 0.163 & -0.95 & 0.061 \\
\hline Education & & 0.131 & 0.228 & 0.168 \\
\hline Experience & & & 0.482 & 0.347 \\
\hline Social status & & & & 0.175 \\
\hline
\end{tabular}

\section{Deriving from the statistical analysis}

1. There exists a positive relation between motivation and job satisfaction.

2. There exists a positive relation between work environment and job satisfaction.

3. There exists a negative relation between weekly working days and job satisfaction.

4. There is a negative relation between years of experience and job satisfaction.

5. There is no significant relation between job satisfaction and gender, level of education \& social status.

The research Hypothesis have been validated by the above statistical results. The surveyed results proved that employees job satisfaction is increased by high motivation and various incentives. Also a higher level of job satisfaction is achieved by improving work environment. Finally the employees are of the opinion to change the weekly working days to be five days only.

\section{Conclusion}


Overall, there was a considerable degree of overlap between the findings; of the present and previous investigations into the relationships between employee motivation, internal work environment and job satisfaction

Job satisfaction represents one of the most complex areas facing today's managers when it comes to managing their employees. Although thousands of papers and research have been conducted on job satisfaction all over the world.

Many studies have demonstrated an unusually large impact on the job satisfaction on the motivation of workers, while the level of motivation has an impact on productivity, and hence also on performance of business organizations.

Based on the conceptual framework of the study, Likert-type questionnaire was filled by (58) employees, which participated in this research by completing the questionnaire. With the assistance of statistical analyses, it was found that the employees in El Isalam Trading company have a high degree of job satisfaction influenced by their motivation, satisfaction of work environment and that they prefer to reduce the working week days to be 5 days and there is no significant relation between job satisfaction and gender, level of education \& social status. employees in El Isalam Trading Company.

\section{References}

Cranny, Smith, \& Stone. (1992). Deconstructing job satisfaction: separating evaluations, beliefs and affective experiences. Human Resource Management Review, 12, 173-194.

HANSIA, B. (2009). Factors influencing job satisfaction, http://www.nmmu.ac.za/documents/theses/BRADLEY\%20L\%20HANSIA.pdf

http://www.sacbusiness.org/marketing/john\%20materials/Bus\%20120/herzberg.pdf

Ingram, D. Relationship between Work Environment \& Job Satisfaction in an Organization for Employee Turnover, http://smallbusiness.chron.com/relationship-between-work-environment-job-satisfaction-orga nization-employee-turnover-11980.html

Judge, T., Thoresen, C., Bono, J., \& Patton, G. (2001). The job satisfaction-job performance relationship: A qualitative and quantitative review. Psychological Bulletin, 127, 376-407. http://dx.doi.org/10.1037/0033-2909.127.3.376

Locke, 1976 cited in Brief, A. P., \& Weiss, H. M. (2001). Organizational behavior: affect in the workplace. Annual Review of Psychology, 53, 279-307.

Shief, M. (2001). Motivation and Job Satisfaction, Boise State University, http://edtech2.boisestate.edu/shiefm/portfolio/Learner\%20Motivation_IPT564_.pdf

Weiss, H. M. (2002). Deconstructing job satisfaction: separating evaluations, beliefs and affective experiences. Human Resource Management Review, 12, 173-194. 


\section{Macrothink}

Journal of Management Research

ISSN 1941-899X 2013, Vol. 5, No. 1

Weiss, H. M. (2002). Deconstructing job satisfaction: separating evaluations, beliefs and affective experiences. Human Resource Management Review', 12, 173-194. http://dx.doi.org/10.1016/S1053-4822(02)00045-1

\section{Questionnaire}

TOPIC: Measuring Level of job satisfaction

An applied study at El- Islam Training Company for auto spare parts

Dear employees,

This study attempts to measure y Level of job satisfaction at El- Islam Training Company for auto spare parts

Information given is confidential and will be used for academic purposes. Your cooperation in providing true information and honest views is highly appreciated.

Thank You

Researcher

Dr.Amir Abou Elnaga

\section{JOB SATISFACTION QUESTIONNAIRE}

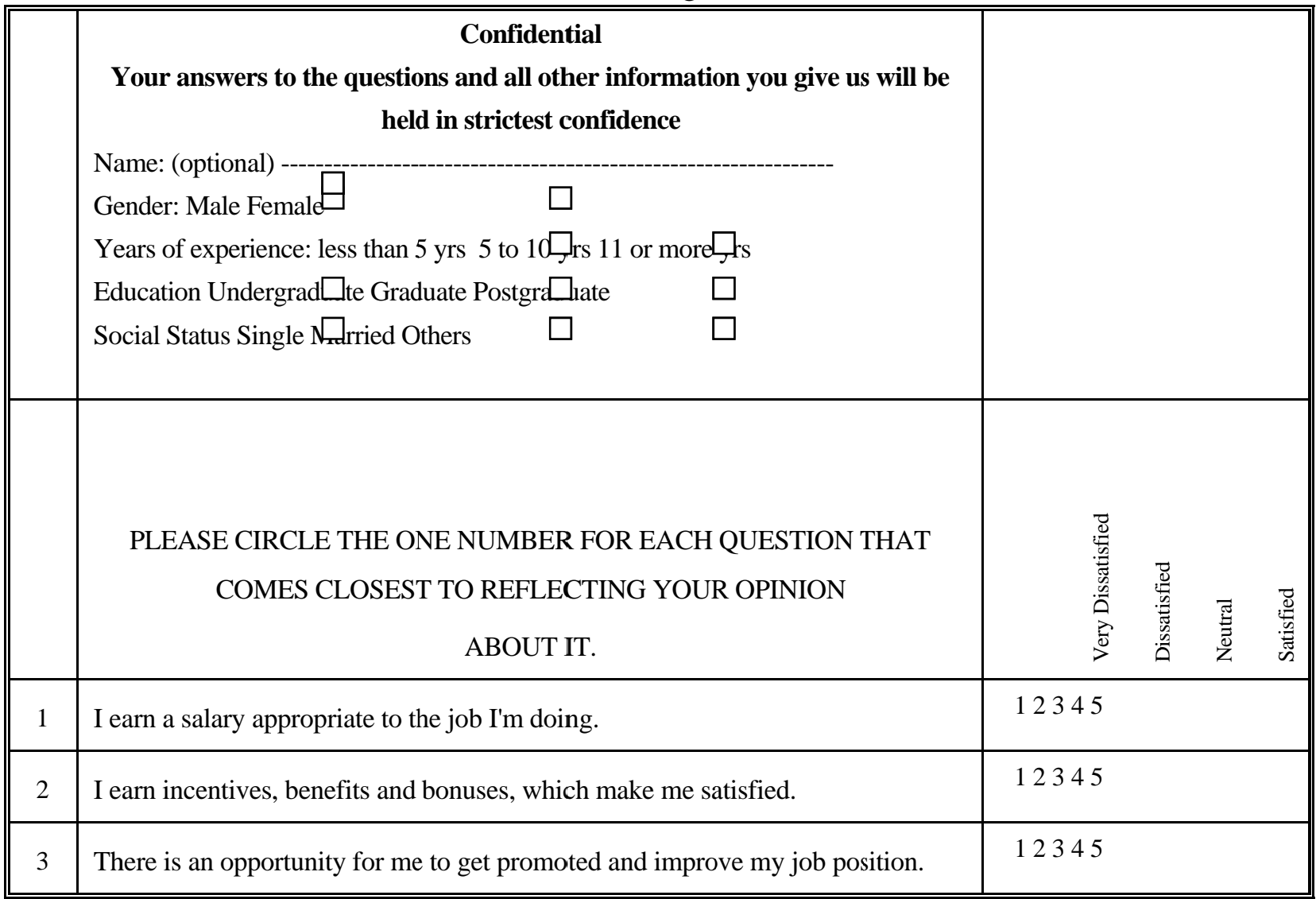




\begin{tabular}{|c|c|c|}
\hline 4 & My current job is appropriate with my years of experience. & 12345 \\
\hline 5 & I feel secured with my current and future job. & 12345 \\
\hline 6 & I'm being respected and appreciated for performing my job from everyone. & 12345 \\
\hline 7 & I find cooperation and good relations with my colleagues. & 12345 \\
\hline 8 & I feel comfortable with type of supervision from my managers. & 12345 \\
\hline 9 & I enjoy a certain degree of freedom and independence in performing my job. & 12345 \\
\hline 10 & There is coordination between the different job divisions. & 12345 \\
\hline 11 & $\begin{array}{l}\text { There are available capabilities that enable me to develop my work and improve } \\
\text { performing my job. }\end{array}$ & 12345 \\
\hline 12 & $\begin{array}{l}\text { The working conditions are suitable concerning cleanliness, ventilation and } \\
\text { equipment. }\end{array}$ & 12345 \\
\hline 13 & The job/ work design enables two days off instead of one day only. & 12345 \\
\hline 14 & The capability to accomplish the week's work in 5 days instead of 6 . & 12345 \\
\hline 15 & Eight hour working per day is sufficient to perform your work efficiently & 12345 \\
\hline 16 & I wish to continue with my job for my entire life. & 12345 \\
\hline 17 & I do not think of moving to another company. & 12345 \\
\hline 18 & I feel happy performing my job. & 12345 \\
\hline 19 & I trust I can achieve success and my ambition through my current job. & 12345 \\
\hline 20 & I feel belonging and loyalty towards my job and my company. & 12345 \\
\hline
\end{tabular}

